\author{
О. В. Ніколаєва ${ }^{1}$, С. А. Петров \\ ОДЕСЬКИЙ НАЦІОНАЛЬНИЙ МЕДИЧНИЙ УНІВЕРСИТЕТ \\ ОДЕСЬКИЙ НАЦІОНАЛЬНИЙ УНІВЕРСИТЕТ ІМЕНІ І. І. МЕЧНИКОВА
}

\title{
ЗАГАЛЬНА ОКСИДАНТНА ТА АНТИОКСИДАНТНА АКТИВНІСТЬ ПРИ АЛОТРАНСПЛАНТАЦІЇ ЕМБРІОНАЛЬНОЇ ЧЕРЕВНОЇ М'ЯЗОВОЇ ТКАНИНИ В ЩУРІВ
}

Вступ. Алотрансплантація ембріональної тканини є одним з актуальних напрямків у сучасній теоретичній і медичній біохімії, які розробляють для стимуляції та відновлення фрунцій організму. Алотрансплантацію ембріональної тканини розглядають як можливу альтернативу традиційним, консервативним методам лікування, а також як методологічну основу експериментальних розробок.

Мета дослідження - вивчити вплив алотрансплантації ембріональної черевної м'язової тканини в щурів на загальну оксидантну та антиоксидантну активність.

Методи дослідження. Для алотрансплантації ембріональної м'язової тканини використовували ембріонів строком 2-3 тижні. Під ефрірним наркозом в асептичних умовах тварину фріксували до хірургічної дошки в положенні лежачи на спині, операційне поле виголювали і тричі обробляли антисептиком. В ембріонів вилучали черевну м'язову тканину, яку фріксували лігатурою до черевної стінки дорослого щура. Рану пошарово щільно зашивали вузловим швом. Алотрансплантацію проводили згідно з хірургічними правилами операцій на м'язах. Досліджувані показники визначали на першу, третю та сьому доби після операційного втручання в тканині донора та тканині реципієнта. Підсадку сорормованої тканини та удавану операцію проводили для того, щоб виключити дію як самої операції, так і ефекту підсадки тканини, щоб виявити дію ембріональної тканини на сорормовану. Тому кожен показник досліджували не тільки при підсадці ембріональної тканини, але й при удаваній операції та підсадці сорормованої тканини до сфоормованої, і порівнювали аналогічні показники при всіх цих трьох видах втручань.

Результати й обговорення. Отримані результати щодо загальної оксидантної активності свідчать про те, що удавана операція та алотрансплантація ембріональної тканини призвели до розвитку оксидативного стресу в досліджуваних м'язах.

Висновки. Загальна оксидантна активність проявляється лише на сьому добу дослідження як при удаваній операції, так і при алотрансплантації ембріональної м'язової тканини в усіх досліджуваних тканинах. Загальна антиоксидантна активність визначається в усі строки дослідження після проведення всіх хірургічних маніпуляцій як у тканині донора, так і в тканині реципієнта.

КЛЮчОВІ СЛОВА: алотрансплантація; м'язова тканина; ембріональна тканина; загальна антиоксидантна активність; оксидативний стрес.

ВСТУП. Терапія за допомогою ембріональних тканин включає в себе специфрічні й неспецифрічні механізми, які ґрунтуються на модуляції процесів регенерації, репарації, проліферації та дисеренціювання і реалізуються на генетичному й епігеномному рівнях. Розкриття цих механізмів може бути вирішальною умовою для розробки нових методів терапії патологічних станів, пов'язаних із порушенням морфогенезу, насамперед онкологічних захворювань. Алотрансплантація ембріональної тканини є одним 3 актуальних напрямків у сучасній теоретичній і медичній біохімії, які розробляють для стимуляції та віднов(с) О. В. Ніколаєва, С. А. Петров, 2019. лення функцій організму. Алотрансплантацію ембріональної тканини розглядають як можливу альтернативу традиційним, консервативним методам лікування, а також як методологічну основу експериментальних розробок [1]. При цьому внаслідок надмірного надходження в організм активних фрорм кисню виникає оксидативний стрес [2]. Поступово розвивається комплекс неспецифічних змін метаболізму. Оксидативний стрес $є$ важливим модулятором регенерації скелетних м'язів після травмування. Делікатний баланс між експресією активних фрорм кисню, експресією та активністю антиоксидантних ензимів відіграє важливу роль у підтримці 
м'язового гомеостазу. Вважають, що антиоксидантні ензими беруть участь у регуляції фріброзу скелетних м'язів. Посилений оксидативний стрес $€$ основним механізмом ушкодження м'язів. Профрілактику окидативного стресу розглядають як засіб для терапевтичного лікування м'язової дистрофії. Проте через труднощі вивчення ролі оксидативного стресу в підтримці м'язового гомеостазу ще багато питань потребує подальшого дослідження, щоб пояснити роль цього стресу в м'язовій регенерації [3].

Мета дослідження-вивчити вплив алотрансплантації ембріональної черевної м'язової тканини в щурів на загальну оксидантну та антиоксидантну активність.

МЕТОДИ ДОСЛІДЖЕННЯ. Для алотрансплантації ембріональної м'язової тканини використовували ембріонів строком 2-3 тижні. Під есрірним наркозом в асептичних умовах тварину оріксували до хірургічної дошки в положенні лежачи на спині, операційне поле виголювали і тричі обробляли антисептиком (йодобак). В ембріонів вилучали черевну м'язову тканину (рис. 1, A), яку фріксували лігатурою до черевної стінки дорослого щура (рис. 1, Б, В). Рану по-

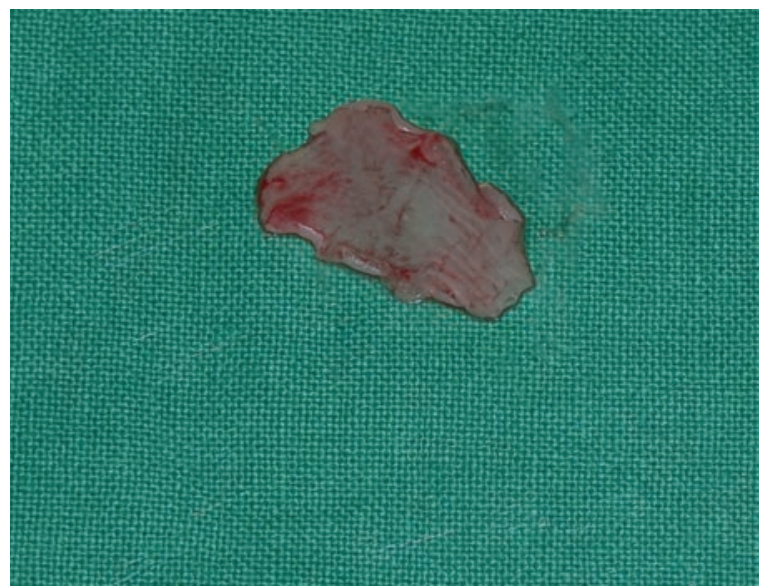

A

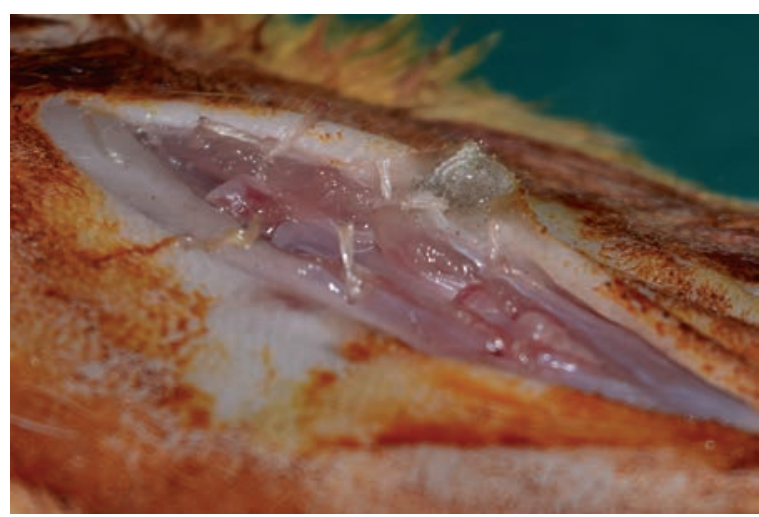

B шарово щільно зашивали вузловим швом (рис. 1, Г) [4].

Алотрансплантацію проводили згідно 3 хірургічними правилами операцій на м'язах [5]. Трансплантацію м'язової тканини, взятої у тварин з одного посліду, проводили за такою самою схемою, що і алотрансплантацію. Донорами черевної м'язової тканини слугували щури-самці з одного посліду. Удавану операцію проводили для порівняння впливу хірургічного втручання на досліджувані показники. Контролем слугувала м'язова тканина тварин, яка не підлягала хірургічним втручанням.

Ми використовували ці методичні прийоми для того, щоб виключити дію як самої операції, так і есректу підсадки тканини. Тому кожен показник досліджували не тільки при підсадці ембріональної тканини, але й при удаваній операції та підсадці сорормованої тканини до сорормованої, і порівнювали аналогічні показники при всіх цих трьох видах втручань. У роботі строго дотримувались етичних принципів проведення експериментальних досліджень $з$ урахуванням положень Європейської конвенції про захист хребетних тварин, що використовуються для дослідних та інших наукових цілей (Страсбург,

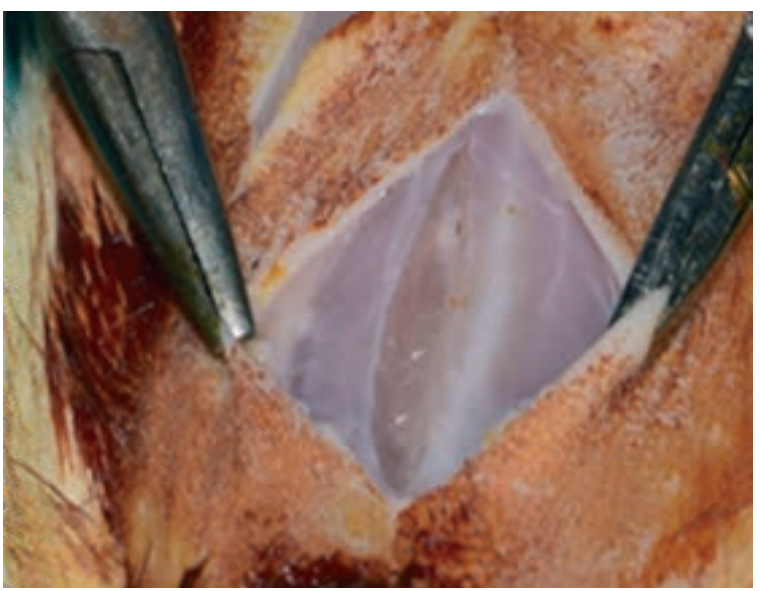

Б

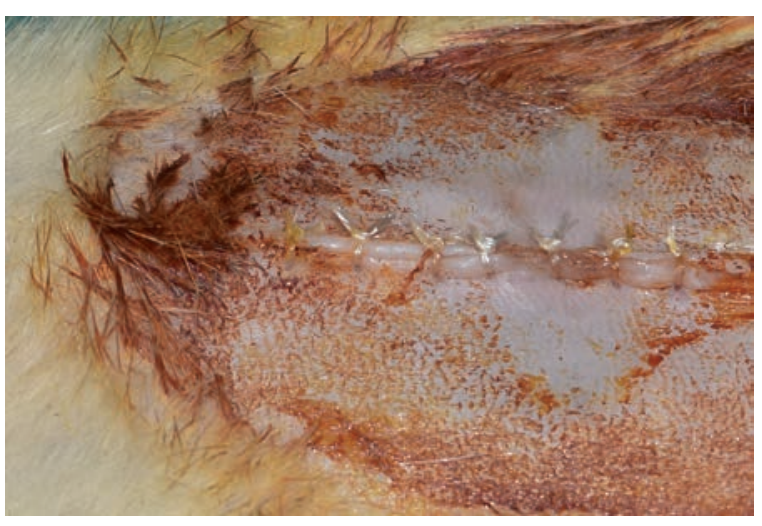

$\Gamma$

Рис. 1. Хід алотрансплантації ембріональної черевної м'язової тканини. 
1986) і Закону України "Про захист тварин від жорстокого поводження". Щурів виводили з експерименту шляхом пропускання електричного струму через довгастий мозок. Досліджувані показники визначали на 1-шу, 3-тю і 7-му доби після операційного втручання в тканині донора та тканині реципієнта. Загальну антиоксидантну активність (ЗАА) визначали методом, який оснований на визначенні малонового діальдегіду (МДА) як продукту окиснення твіну-80 при інгібуванні аскорбатом. Загальну оксидантну активність (3ОА) оцінювали за накопиченням у реакційній суміші кінцевого продукту пероксидного окиснення - малонового діальдегіду [6]. Отримані дані обробляли статистично за Стьюдентом. Спочатку обчислювали середньоарисрметичне значення (Мср) та розраховували середньоквадратичне відхилення (m). Використовуючи таблицю Стьюдента і значення t, визначали рівень значущості р. Відмінності між середніми значеннями вважали достовірними при p $\leq 0,05$.

РЕЗУЛЬТАТИЙ ОБГОВОРЕННЯ. На ПОчаТКУ дослідження ми визначали, як впливає кожна 3 проведених хірургічних маніпуляцій на оксидантний статус м'язової тканини, показником якого в нашому експерименті $€ 30$ А (рис. 2). Було встановлено, що вона визначається лише на 7-му добу дослідження при алотрансплантації ембріональної тканини та удаваній операції. Це свідчить про виникнення оксидативного стресу в досліджуваних тканинах. На достатньо пізніх етапах його профрілактика необхідна для терапевтичного лікування м'язової дистрофії. Проте через причетність оксидативного стресу до м'язового гомеостазу ще багато питань потребує подальшого дослідження, щоб пояснити роль цього стресу в м'язовій регенерації $[7,8]$.

Наступним етапом дослідження було встановити поведінку антиоксидантної системи на

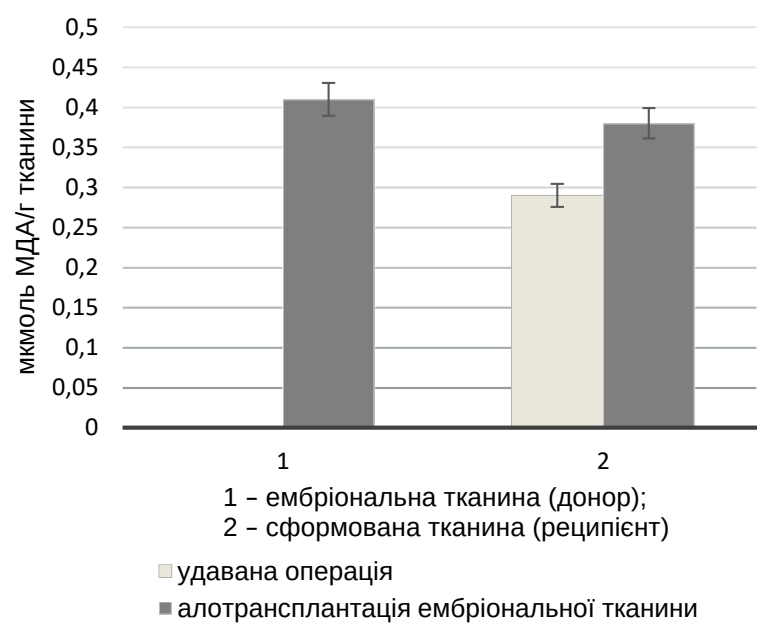

Рис. 2. Загальна оксидантна активність при хірургічних втручаннях на 7-му добу дослідження (мкмоль МДА/г тканини).

виникнення оксидативного стресу. В таблиці 1 наведено результати удаваної операції, які свідчать про те, що антиоксидантний захист вмикається відразу після операції. У контролі загальної антиоксидантної активності не визначали, що узгоджується з результатами минулих досліджень рівня МДА [9].

У таблиці 2 наведено результати визначення ЗАА при підсадці ссрормованої тканини. Як у тканині реципієнта, так і в тканині донора вона зростала протягом усіх досліджуваних строків.

У таблиці 3 наведено результати дослідження впливу алотрансплантації черевної м'язової тканини на ЗАА. Загальна антиоксидантна активність збільшувалась як у тканині донора, так і в тканині реципієнта, що свідчить про появу форм кисню в тканинах та активне включення антиоксидантного захисту клітин.

Було проведено три види хірургічних втручань. Ці методичні прийоми використано для того, щоб виключити дію як самої операції, так і есректу підсадки тканини. Тому кожен показник

\begin{tabular}{|c|c|c|}
\hline & \multicolumn{2}{|c|}{ 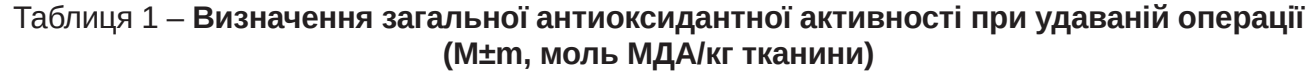 } \\
\hline & Термін дослідження, доба & Черевна м'язова тканина дорослого щура \\
\hline & Контроль (без підсадки) & Не визначають \\
\hline & 1-ша & $0,49 \pm 0,03^{*}$ \\
\hline & 3-тЯ & $0,31 \pm 0,03^{*}$ \\
\hline & 7-мa & $0,10 \pm 0,02^{*}$ \\
\hline
\end{tabular}

Примітка. Тут і в таблицях 2, 3: * - достовірно відносно контролю $(p \leq 0,05)$.

Таблиця 2 - Визначення загальної антиоксидантної активності при трансплантації м'язової тканини, взятої в щурів з одного посліду (M $\pm m$, моль МДА/кг тканини)

\begin{tabular}{|c|c|c|}
\hline Термін дослідження, доба & Черевна м'язова тканина реципієнта & Черевна м'язова тканина донора \\
\hline Контроль (без підсадки) & Не визначають & Не визначають \\
\hline 1-ша & $0,21 \pm 0,02^{*}$ & $0,24 \pm 0,01^{*}$ \\
\hline 3-тя & $0,21 \pm 0,01^{*}$ & $0,22 \pm 0,02^{*}$ \\
\hline 7-ма & $0,29 \pm 0,01^{*}$ & $0,31 \pm 0,02^{*}$ \\
\hline
\end{tabular}


Таблиця 3 - Визначення загальної антиоксидантної активності при алотрансплантації ембріональної м'язової тканини ( $\mathrm{M} \pm \mathrm{m}$, моль МДА/кг тканини)

\begin{tabular}{|c|c|c||}
\hline \hline Термін дослідження, доба & $\begin{array}{c}\text { Черевна м'язова тканина дорослого } \\
\text { щура (реципієнт) }\end{array}$ & $\begin{array}{c}\text { Черевна м'язова тканина } \\
\text { ембріона (донор) }\end{array}$ \\
\hline Контроль (без підсадки) & Не визначають & Не визначають \\
\hline 1-ша & $0,07 \pm 0,01^{*}$ & $0,09 \pm 0,01^{*}$ \\
\hline 3-тя & $0,10 \pm 0,02^{*}$ & $0,08 \pm 0,02^{*}$ \\
\hline 7-ма & $0,09 \pm 0,01^{*}$ & $0,16 \pm 0,03^{*}$ \\
\hline
\end{tabular}

досліджували не тільки при підсадці ембріональної тканини, але й при удаваній операції та підсадці сорормованої тканини до сорормованої, і порівнювали аналогічні показники при всіх цих трьох видах втручань. Головним завданням було визначити, чи призводять хірургічні втручання до розвитку оксидативного стресу та наскільки захисні біохімічні системи організму справляються із цим стресом.

Отримані результати щодо загальної оксидантної активності свідчать про те, що удавана операція та алотрансплантація ембріональної тканини призвели до розвитку оксидативного стресу в досліджуваних м'язах. Такий самий есрект спостерігали і при дослідженнях стегнової м'язової тканини [10]. Алотрансплантація являє собою стресорактор для організму, в результаті чого відбувається окиснення відновлених компонентів мембран наявних клітин, що призводить до виникнення супероксидних аніонів [11]. Стрес $€$ одним з найбільш активно досліджуваних фрізіологічних станів організму, який зачіпає всі рівні його організації, насамперед клітинний. Захисні механізми антиоксидантної системи вмикаються вже в ранні строки після операцій, про що свідчать не тільки наведені в даній роботі показники, але й раніше отримані результати [12].

3 літератури відомо, що активні фрорми кисню генеруються в скелетних м'язах під час як загальної, так і скорочувальної активності. Міогенні клітини забезпечені антиоксидантними ензимами, такими, як супероксиддисмутаза, каталаза, глутатіонпероксидаза та інші. Ці ензими не лише нейтралізують надлишок активних форм кисню, але також впливають на міогенну регенерацію в декілька етапів: впливають на запальну реакцію після травмування, підвищують життєздатність і проліферацію м'язових супутникових клітин та міобластів, впливають на їх диореренціацію. Нарешті, антиоксидантні ензими регулюють також процеси, що супроводжують регенерацію м'язів, - індукують ангіогенез і зменшують фріброз [3].

Антиоксидантні методи лікування можна використовувати в терапії, щоб уникнути або відкласти м'язове виснаження при патологіях [13-16].

ВИСНОВКИ. Загальна оксидантна активність провляється лише на 7-му добу дослідження як при удаваній операції, так і при алотрансплантації ембріональної м'язової тканини в усіх досліджуваних тканинах. Загальна антиоксидантна активність визначається в усі строки дослідження після проведення всіх хірургічних маніпуляцій як у тканині донора, так і в тканині реципієнта.

\section{СПИСОК ЛІТЕРАТУРИ}

1. Станков Д. С. Нейротрансплантация в лечении травмы спинного мозга / Д. С. Станков, П. И. Катуниян, Н. Е. Крашенников // Russian journal of transplantology and artificial organs. - 2003. - № 1. - C. 44-45.

2. Pochernyaeva V. F. Determination of sources of reactive oxygen species / V. F.Pochernyaeva, O. I. Tsebrzhinskiy, N. V. Shish // Буковин. мед. вісн. - 2006. - 9, № 2. - P. 214-215.

3. The role of oxidative stress in skeletal muscle injury and regeneration: focus on antioxidant enzymes / M. Kozakowska, K. Pietraszek-Gremplewicz, A. Jozkowicz, J. Dulak // Journal of Muscle Research and Cell Motility. - 2015. - 36 (6). - P. 377-393. doi: 10.1007/ s10974-015-9438-9
4. Регенерация скелетной мышечной ткани экспериментальных животных, индуцированная биоматериалом / А. И. Лебедева, С. А. Муслимов, Л. А. Мусина, Д. А. Щербаков // International Journal of Experimental Education. - 2014. - № 3. - C. 68-71.

5. Литтманн И. Оперативная хирургия / И. Литтманн. - Будапешт : Изд-во академии наук Венгрии, 1985. - С. 1055-1056.

6. Горячковский А. М. Клиническая биохимия в лабораторной диагностике / А. М. Горячковский. 3-е изд. - Одесса : Экология, 2005. - 616 с.

7. Ebselen reduces inflammation and microvascular perfusion failure after blunt skeletal muscle injury of the rat / P. Gierer, J. Röther, T. Mittlmeier [et al.] // Journal 
Trauma. - 2010. - 68 (4). - P. 853-858. DOI: 10.1097/ TA.0b013e3181b28a18.

8. Ghaly A. Aging-associated oxidative stress modulates the acute inflammatory response in skeletal muscle after contusion injury / A. Ghaly, D. Marsh // Experimental Gerontology. - 2010. - 45. - P. 381-388. DOI: 10.1016/j. exger.2010.03.004.

9. Кулібаба О. В. Вміст малонового діальдегіду при алотрансплантації ембріональних м'язових тканин у щурів / О. В. Кулібаба // Одес. мед. журн. -2015. № 5 (151). - C. 11-14.

10. Визначення загальної оксидантної активності при алотрансплантації ембріональної м'язової тканини у щурів / О. В. Ніколаєва, С. М. Кобильник, М. Д. Кагляк, С. А. Петров // Development of natural sciences: problems and solutions : Матеріали міжнар. наук. та практ. конфр. - Брно, 2018. - С. 199-202.

11. Меньшикова Е. Б. Оксидативный стресс. Прооксиданты и антиоксиданты / Е. Б. Меньшикова, В. 3. Ланкин, Н. К. Зенков. - М. : Слово, 2006. - 556 с.

12. Kulibaba O. V. Condition of glutathione (GSH) metabolism system at allotransplantation of embryonic muscule tissue at rats / O. V. Kulibaba, S. A. Petrov // 2nd Eurasion Multidisciplinary Forum, 2014. - 2. - P. 202-206.

13. Barbieri E. Reactive oxygen species in skeletal muscle signaling / E. Barbieri, P. Sestili // Journal of Signal Transduction. - 2012. - P. 982794. Doi: 10.1155/ 2012/982794

14. Contribution of oxidative stress to pathology in diaphragm and limb muscles with Duchenne muscular dystrophy / J. H. Kim, H. B. Kwak, L. V. Thompson, M. Lawler // Journal of Muscle Research and Cell Motility. - 2013. - 34 (1). - P. 1-13. DOI: 10.1007/s10974012-9330-9.

15. Reactive oxygen species: impact on skeletal muscle // S. K. Powers, L. L. Ji, A. Kavazis, M. J. Jackson // Comprehensive Physiology. - 2011. -1 (2). - P. 941-969. doi: 10.1002/cphy.c100054.

16. Low intensity training decreases markers of oxidative stress in skeletal muscle of $\mathrm{mdx}$ mice // J. J. Kaczor, J. E. Hall, E. Payne, M. A. Tarnopolsky // Free Radical Biology \& Medicine. - 2007. - 43 (1). P. 145-154. DOI: 10.1016/j.freeradbiomed.2007.04.003.

\section{REFERENCES}

1. Stankov, D.S., Katunyan, P.I., \& Krasheninnikov, N.E. (2003). Neyrotransplantasiya v lechenii travmi spinnogo mozga [Neurotransplantation in the treatment of spinal cord injury]. Russian Journal of Transplantology and Artificial Organs, 1, 44-45 [in Russian].

2. Pochernyaeva, V.F., Tsebrzhinskiy, O.I., \& Shish, N.V. (2006). Determination of sources of reactive oxygen species. Bucovynskyi med. visnyk - Bukovyna Medical Bulletin, 9 (2), 214-215.

3. Kozakowska, M., Pietraszek-Gremplewicz, K., Jozkowicz, A., \& Dulak, J. (2015). The role of oxidative stress in skeletal muscle injury and regeneration: focus on antioxidant enzymes. Journal of Muscle Research and Cell Motility, 36 (6), 377-393. doi: 10.1007/s10974-0159438-9

4. Lebedeva, A.I., Muslimov, S.A., Musina, L.A., \& Shcherbakov, D.A. (2014). Regeneratsiya skeletnoy myshechnoy tkani eksperimentalnikh zhivotnikh, indutsirovannaya biomaterialom Alloplant [Regeneration of skeletal muscle tissue of the experimental animals induced Alloplant biomaterial]. International Journal of Experimental Education, 3, 68-71 [in Russian].

5. Littmann, I. (1985). Operative surgery. Budapest: Publishing house of the Academy of Sciences of Hungary.

6. Goryachkovskiy, A.M. (2005). Klinicheskaya biokhimiya v laboratornoy diagnostike [Clinical biochemistry in laboratory diagnostics]. Odessa: Ekologiya - 3rd edition, revised and enlarged [in Russian].

7. Gierer, P., Röther, J., Mittlmeier, T., Gradl, G., \& Vollmar, B. (2010). Ebselen reduces inflammation and microvascular perfusion failure after blunt skeletal muscle injury of the rat. Journal Trauma, 68 (4), 853-858. DOI: 10.1097/TA.0b013e3181b28a18.

8. Ghaly, A., \& Marsh, D. (2010). Aging-associated oxidative stress modulates the acute inflammatory response in skeletal muscle after contusion injury. Experimental Gerontology, 45, 381-388. DOI: 10.1016/j. exger.2010.03.004.

9. Kulibaba, O.V. (2015). Vmist malonovoho dialdehidu pry alotransplantasii embrionalnykh miazovykh tkanyn u shchuriv [The content of malondialdehyde in the embryonic muscle tissues allotransplantation in rats]. Odeskyi medychnyi zhurnal - Odesa Medical Journal, 5 (151), 11-14 [in Ukrainian].

10. Nikolaieva, O.V., Kobylnik, S.M., Kahliak, M.D., \& Petrov, S.A. (2018). Vyznachennia zahalnoi oksydantnoi aktyvnosti pry alotransplantatsii embrionalnoi miazovoi tkanyny u shchuriv [Estimation of total oxidation activity in embryonic muscle tissue allotransplantation in rats]. Materials of the International Scientific and Practical Conference "Development of Natural Sciences: Problems and Solutions, Brno. (pp.199-202) [in Ukrainian].

11. Menshikova, E.B., Lankin, V.Z., \& Zenkov, N.K. (2006). Oxidativnyy stress. Prooksidanty $i$ antioksidanty [Oxidative stress. Prooxidants and antioxidants]. Moscow: Slovo [in Russian].

12. Kulibaba, O.V., \& Petrov, S.A. (2014). Condition of glutathione (GSH) metabolism system at allotransplantation of embryonic muscule tissue at rats. 2nd Eurasion Multidisciplinary Forum, 2, 202-206.

13. Barbieri, E., \& Sestili, P. (2012). Reactive oxygen species in skeletal muscle signaling. Journal of Signal Transduction, 982794. Doi: 10.1155/2012/982794. 
14. Kim, J.H., Kwak, H.B., Thompson, L.V., \& Lawler, M. (2013). Contribution of oxidative stress to pathology in diaphragm and limb muscles with Duchenne muscular dystrophy. Journal of Muscle Research and Cell Motility, 34 (1), 1-13. DOI: 10.1007/s10974-0129330-9.

15. Powers, S.K., Ji, L.L., Kavazis, A.N., \& Jackson, M.J. (2011). Reactive oxygen species: impact on skeletal muscle. Comprehensive Physiology, 1 (2), 941969. doi: 10.1002/cphy.c100054.

16. Kaczor, J.J., Hall, J.E., Payne, E. \& Tarnopolsky, M.A. (2007). Low intensity training decreases markers of oxidative stress in skeletal muscle of $\mathrm{mdx}$ mice. Free Radical Biology \& Medicine, 43 (1), 145-154. DOI: 10.1016/j.freeradbiomed.2007.04.003.

ОБЩАЯ ОКСИДАНТНАЯ И АНТИОКСИДАНТНАЯ АКТИВНОСТЬ ПРИ АЛЛОТРАНСПЛАНТАЦИИ ЭМБРИОНАЛЬНОЙ БРЮШНОЙ МЫШЕЧНОЙ ТКАНИ У КРЫС

\section{Резюме}

Вступление. Аллотрансплантация эмбриональной ткани является одним из актуальных направлений в современной теоретической и медицинской биохимии, которые разрабатывают для стимуляции и возобновления фрункций организма. Аллотрансплантацию эмбриональной ткани рассматривают как возможную альтернативу традиционным, консервативным методам лечения, а также как методологическую основу экспериментальных разработок.

Цель исследования - изучить влияние аллотрансплантации эмбриональной брюшной мышечной ткани у крыс на общую оксидантную и антиоксидантную активность.

Методы исследования. Для аллотрансплантации эмбриональной мышечной ткани использовали эмбрионов сроком 2-3 недели. Под эфирным наркозом в асептических условиях животное фриксировали к хирургической доске в положении лежа на спине, операционное поле выбривали и трижды обрабатывали антисептиком. У эмбрионов изымали брюшную мышечную ткань, которую фриксировали лигатурой к брюшной стенке взрослой крысы. Рану послойно плотно зашивали узловым швом. Аллотрансплантацию проводили согласно хирургическим правилам операций на мышцах. Исследуемые показатели определяли на первые, третьи и седьмые сутки после операционного вмешательства в ткани донора и ткани реципиента. Подсадку сфрормированной ткани и ложную операцию проводили для того, чтобы исключить действие как самой операции, так и эфоректа подсадки ткани, чтобы выявить действие эмбриональной ткани на сфрормированную. Поэтому каждый показатель исследовали не только при подсадке эмбриональной ткани, но и при ложной операции и подсадке сфрормированной ткани к сформированной, и сравнивали аналогичные показатели при всех этих трех видах вмешательств.

Результаты и обсуждение. Полученные результаты относительно общей оксидантной активности свидетельствуют о том, что ложная операция и аллотрансплантация эмбриональной ткани привели к развитию оксидативного стресса в исследуемых мышцах.

Выводы. Общая оксидантная активность проявляется только на седьмые сутки исследования как при ложной операции, так и при аллотрансплантации эмбриональной мышечной ткани во всех исследуемых тканях. Общая антиоксидантная активность определяется во все сроки исследования после проведения всех хирургических манипуляций как в ткани донора, так и в ткани реципиента.

КЛЮЧЕВЫЕ СЛОВА: аллотрансплантация; мышечная ткань; эмбриональная ткань; общая антиоксидантная активность; оксидативный стресс. 


\section{THE TOTAL OXIDATIVE AND ANTIOXIDANT ACTIVITY IN THE ALLOTRANSPLANTATION OF EMBRYONIC ABDOMINAL MUSCLE TISSUE IN RATS}

Introduction. Allotransplantation of embryonic tissue is one of the most important directions in modern theoretical and medical biochemistry, which is being developed for stimulation and restoration of organism functions. Allotransplantation of embryonic tissue is considered possible alternative to traditional, conservative methods of treatment, as well as a methodological basis for experimental development.

The aim of the work - to investigate the effect of embryonic abdominal muscle tissue allotransplantation on the total oxidative and antioxidant activity.

Research Methods. Embryos aged 2-3 weeks, were used for embryonic muscle tissue allotransplantation. Under ethereal anesthesia under aseptic conditions, the animal was fixed to the surgical board in the position lying on the back; the operating area was shaved, and three times treated with an antiseptic. The embryos' abdominal muscle tissue was removed and fixed with the ligature to the abdominal wall of the adult rat. The wound was tightly sutured in layers using interrupted stitch. The allotransplantation was performed according to the surgical rules of muscle surgery. The investigated indicators were measured on the first, third and seventh day after surgery in the tissue of the donor and the recipient. The transplantation of the formed (non-embryonic) tissue and the false operation were performed in order to eliminate the effect of the operation itself and the effect of tissue transplantation. That was done in order to detect the effect of embryonic tissue on the formed one. Therefore, we measured each indicator not only after transplantation of embryonic tissue, but also after the false operation and after transplantation of the formed tissue to the formed one and compared the same indicator for all three types of intervention.

Results and Discussion. The obtained results of general oxidant activity indicate that false surgery and allotransplantation of embryonic tissue led to the development of oxidative stress in the muscle under investigation.

Conclusions. Thus, it was defined that the total oxidative activity is detected only on the seventh day of the investigation in all examination tissues both during the false operation and at allotransplantation of the embryonic muscle tissue. The total antioxidant activity is detected after the all performed surgical manipulations in both the donor and the recipient's tissue.

KEY WORDS: allotransplantation; muscle tissue; embryonic tissue; total antioxidant activity; oxidative stress.

Отримано 29.01.19

Адреса для листування: О. В. Ніколаєва, Одеський національний медичний університет, вул. Князієвська, 1, Одеса, 65082, Україна, e-mail: evkulibaba@gmail.com. 